\title{
Pegasus Hava Yolları’nın Covid-19 Instagram Paylaşımları Üzerinden Kültürel Boyutların Okunması
}

Cemile ERDEN UZUN, İstanbul Arel Üniversitesi, Meslek Yüksekokulu, Ulaştırma Hizmetleri Bölümü, Öğretim Görevlisi, cemile.erden@outlook.com, (DD 0000-0001-8530-1256

Selma KOÇ AKGÜL, Kocaeli Üniversitesi, İletişim Bilimleri Fakültesi, Gazetecilik Bölümü, Doç. Dr. Öğretim Üyesi, selmakoc68@hotmail.co.uk, (ID) 0000-0001-7889-6749

$\ddot{O} \mathrm{Z}$

Anahtar : $\quad$ Covid-19, Pegasus Hava Yolları, Instagram, Kültürel Boyutlar

Covid-19 salgınını dünyaya yayılmasının ardından gelen birçok kısıtlama ve tedbir yaşantımızda büyük değişikliklere yol açmıştır. Dünyanın genelinde kısıtlama ve tedbirler benzer olsa da hastalı̆̆ın yayılımı farklı ülkelerde farklı gidişatlar seyretmiştir. Yapılan çalışmalarda bu farklılıkların kültürel boyutlar ile açıklanabildiği görülmüştür. Pandemi ile mücadele etmenin ilk adımı teması azaltmak olarak belirlenmiştir. Bu nedenle uçuşlar bir süreliğine askıya alınmıştır. Bu süreçte hava yolları hem iptal olan uçuşlar hakkında bilgi vermek hem de müşteri sadakatini sürdürmek için sosyal medya araçlarımı aktif şekilde kullanmıştır. "Pandemi gidişatın etkileyen kültürel boyutların hava yolu iletişim stratejilerinde de kendine yer bulmakta mıdır?" sorusu çalışmanın problemini oluşturmaktadır. Gönderilerde Türkiye'nin kültürel boyutlarna uygun temalara yer verilip verilmediğini bulmak çalışmanın amacıdır. Yaşam tarzımızı açıklayan kültürel boyutlar aynı zamanda pazarlama çalışmalarında önemli bir rol oynadığı ve bilinçli veya bilinçsiz bir şekilde şirketler tarafindan müşteri ile iletişimde bu boyutlara uygun iletişim kurulduğu öngörülmektedir. Bu kavramlar ekseninde Pegasus Hava Yolu şirketinin, en çok kullanilan sosyal medya araçlarından biri olan Instagram hesabından 27 Mart- 13 Haziran 2020 tarih aralı̆̆ında paylaşılan 33 fotoğraftan Covid-19 kısıtlamaları hakkında olan 23 tanesi içerik analizi yöntemiyle incelenmiştir. Çalışmada Kültürel Boyutlar Kuramı'nın Bireysellik Erillik ve Belirsizlikten Kaçınma boyutları ele alınmıştır. Gönderilerde tespit edilen boyutlar ile Türkiye ulusal boyutları arasında pozitif ilişki tespit edilmiştir. Instagram gönderilerinde kültürel boyutlarn ifade eden temalarn bulunması ve bu boyutlarm toplumsal boyutlarla eşdeğerlik göstermesi, kültürel boyutların hava yollarının sosyal medya iletişim stratejilerinde kendine yer bulduğunu göstermiştir.

Kelimeler 


\section{Reading Cultural Dimensions through Pegasus Airlines' Covid-19 Instagram Posts}

ABSTRACT

Keywords $\quad$ : Covid-19, Pegasus Airlines, Instagram, Cultural Dimensions

\section{EXTENDED ABSTRACT}

After the Covid-19 virus was first seen in China, it was declared a pandemic on March 11,2020 , as a result of its spread throughout the world in a short period of 2-3 months. (Ministry of Health, 2020). Prior to this announcement, some countries stopped their flights to China as a precaution. Over time, flight restrictions have been imposed in countries where the virus is seen intensely. However, with the declaration of the pandemic, international flights came to a standstill. In order to prevent the pandemic, international and even domestic flights have been temporarily suspended. During the pandemic period, one of the most affected sectors due to the reasons mentioned above has been the aviation sector. Passengers were anxiously waiting for the canceled flights during this period. The uncertainty of the dates of the canceled and re-started flights, the inaccuracy of the forecasts, and the fact that the flights were started with some restrictions and precautions arised necessity for airlines to share information with their customers.

Different societies have given different reactions to the rules and measures set by the authorities around the world within the scope of the fight against Covid-19. These different 
reactions have prompted researchers to investigate why. In this direction, the cultural dimensions that reveal the differences of societies have opened an enlightening door for researchers to understand the reasons for these different reactions. It has been seen that some cultural dimensions features play an active role in combating the pandemic.

Airline companies gave information through the announcements they made on their official websites. However, the active use of social media accounts, which directly communicate with passengers, has become a necessity in order to maintain the connection established with the customers and not to lose customer loyalty when flights resume. Therefore, the main assumption of the study is; The cultural dimensions emphasized in the information sharing about the measures and rules regarding Covid-19 and other issues are parallel to the cultural dimensions of the society. Based on this assumption, the study; is to seek whether cultural dimensions suitable for society are included in the posts. The study only covers Pegasus Airlines Instagram account. Data were collected from the date range when flights were stopped and resumed. In the data obtained, power distance, uncertainty avoidance and collectivity dimensions in Hofstede's Cultural Dimensions Theory were sought. The data were analyzed by content analysis method.

The aim of the study is to find out how much the cultural dimensions of Turkey show themselves in the posts shared by the airline company. Thus, it will be understood whether the posts shared by the airline company in line with its communication strategy are suitable for the culture of the customer mass.

Pegasus Airlines was expected to share information in accordance with the Cultural Dimensions of Turkey in its information sharing regarding the pandemic period. When the Instagram posts obtained from a certain date range were subjected to content analysis, it was seen that the high power distance dimension was emphasized 12 times, the high uncertainty avoidance dimension 57 times and the collectivity dimension 8 times. When we look at the cultural dimensions of Turkey, it is seen that the power distance is 66, uncertainty avoidance 85 , collectivity 63 percent. It is seen that there is a positive relationship between numerical values. Despite this, it is expected that the emphasis on power range and collectivity will be a little more. At the end of the study, the hypotheses of the study were confirmed. In addition, it can be said that cultural dimensions do not only express lifestyle, but also play a role in determining the communication strategies of airline companies. The study can be extended with data including longer periods over other airline companies. In addition, comparison studies with other countries and airlines may reveal the importance of cultural dimensions theory in terms of communication strategies. This study provides a brief preview of future studies. 


\section{GíRiş}

Covid-19 virüsünün ilk kez Çin'de görülmesinin ardından 2-3 ay gibi kısa bir sürede Dünya geneline yayılması sonucunda 11 Mart 2020 tarihinde pandemi ilan edilmiştir. (Sağlık Bakanlığı, 2020). Bu sürecin öncesinde bazı ülkeler tedbir amaçlı Çin'e olan uçuşlarını durdurmuştur. Zamanla virüsün yoğun şekilde görüldüğü ülkelerde uçuş kısıtlamalarına gidilmiştir. Ancak pandemi ilanıyla beraber uluslararası uçuşlar durma noktasına gelmiştir. Pandeminin önüne geçebilmek amacıyla yurt dışı hatta yurt içi uçuşlar geçici bir süreliğine durdurulmuştur. Vaka sayılarında düşüş beklendiği için uçuşların ne zaman yeniden başlayacağı konusunda bir dönem belirsizlik oluşmuştur. Pandemi sürecinde yukarıda bahsedilen sebeplerden dolayı en çok etkilenen sektörlerden biri de havacılık sektörü olmuştur. Bu dönemde iptal edilen uçuşlar konusunda yolcular endişeli bir bekleyiş içerisine girmiştir. İptal edilen ve yeniden başlayacak olan uçuşların tarih belirsizliği, öngörülerin tutmaması ve uçuşlara bir takım kısıtlama ve tedbirler ile başlanması hava yollarının müşterilerine karşı bir bilgi paylaşımı zorunluluğunu doğurmuştur.

Covid-19 ile mücadele kapsamında dünya genelinde otoritelerce koyulan kurallara ve tedbirlere farklı toplumlar tarafından farklı tepkiler verilmiştir. Bu farklı tepkiler araştırmacıları bunun nedeninin araştırmaya itmiştir. $\mathrm{Bu}$ doğrultuda toplumların farklılıklarını ortaya koyan kültürel boyutlar araştırmacılara bu farklı tepkilerin nedenlerini anlamak konusunda aydınlatıcı bir kapı açmıştır. Bazı kültürel boyutlar özelliklerinin pandemi ile mücadele konusunda etkin rol oynadığı görülmüştür. Hava yolları şirketlerinin kurumsal iletişim ve pazarlama aracı olarak kullandıkları sosyal medya hesapları pandemi döneminde kullanıcılarıyla etkileşim sağladıkları araçların başında gelmiştir. Hava yolu şirketleri resmi internet sitelerinden yaptıkları duyurular ile bilgilendirmeler yapmıştır. Ancak yolcular ile doğrudan iletişim kurulan sosyal medya hesaplarının aktif kullanımı müşteri ile kurulan bağın devamını sağlamak ve uçuşlar tekrar başladığında müşteri sadakatini kaybetmemek için gereklilik haline geldiği görülmektedir. Tedbirler ve kısıtlamalara uyulması konusunda yolcuların yönlendirilmesi de yine sosyal medya aracılığıyla sağlanmaktadır. Bu yönüyle Covid-19 pandemisiyle ilgili tedbir ve kuralların yer aldığı süreçte yapılan sosyal medya bilgilendirme paylaşımlarında, vurgulanan kültürel boyutların toplumun kültürel boyutları ile ne kadar örtüştüğü, kültürel boyutların pandemi sürecine etkisi ve şirketlerin iletişim stratejisinin müşteri kitlesinin kültürüne göre mi belirlendiği sorularının yanıtı önem kazanmaktadır.

Çalışma bu soruların yanıtlarını tespit etmek amacıyla tanımlayıcı bir araştırma olarak tasarlanmış olup ulusal hava yolu şirketlerinin sosyal medya paylaşımlarında topluma uygun kültürel boyutların gönderilerde yer alıp almadığıyla ilgili iletilerin nasıl tasarlandığı bulgulanmak istenmiştir. Ülkenin kültürel boyutları ile sosyal medya paylaşımlarının uyumlu olması gerektiği varsayımından yola çıkılmıştır. Amaçlı örneklem yöntemiyle özel bir hava 
yolu şirketi olan ve özellikle yurtiçi uçuşlarda yoğun hizmet veren Pegasus Hava Yolu şirketi Instagram hesabı paylaşımları araştırma nesnesi olarak seçilmiştir. Veriler uçuşların durdurulduğu ve tekrar başladığı tarih aralığından toplanmıştır. Elde edilen veriler Hofstede'in Kültürel Boyutlar Kuramındaki yüksek güç aralığı, yüksek belirsizlikten kaçınma ve kolektiflik boyutlarının arandığı içerik analizi yöntemiyle incelenmiştir.

\section{COVID-19 PANDEMISINIIN TÜRK SIVIL HAVACILIĞI ÜZERINNDEKI ETKİİ}

Sivil Havacılık Genel Müdürlüğü (SHGM) resmi sitesinde korona virüs salgını nedeniyle ilk uçuş iptali Çin ve Vietnam için 23 Şubat 2020 tarihinde duyurulmuştur. 15 Mart 2020 tarihinde Almanya, Avusturya, Belçika, Fransa, Hollanda, İspanya, İsveç, Norveç, Danimarka olmak üzere toplam 9 Avrupa ülkesine uçuşlar karşılıklı olarak durdurulacağı ve sadece öğrenci gibi yurda dönmek isteyenlerin bu tarihe kadar sadece yurda dönüş uçuşları olacağını ve yurda dönenlerin 14 gün karantinaya alınacağını belirten bir duyuru yayımlamıştır. 21 Mart 2020'de ise toplamda 71 ülkeye kargo, hükümet, acil tıbbi yardım ve teknik sebeplerle acil iniş haricinde karşılıklı uçuşun durdurulduğunu 28 Mart 2020' de ise tüm dış hat uçuşlarının durdurulduğunu sadece THY tarafından kısıtlı iç hat uçuşu yapılacağını açıklamıştır. 29 Mart 2020 tarihinde tüm hava yolu ile seyahat edecek yolcuların seyahat izin belgesi alması zorunluluğu getirilmiştir. (SHGM, 2021)

Uçuşların tekrar başlaması ile ilgili, Ulaştırma ve Altyapı Bakanı Adil Karaismailoğlu, 10 Haziran'dan itibaren kademeli olarak 40 ülkeye uçak seferlerini başlatmak için planlama yaptıklarını açıklamıştır (Euronews, 2020a). Sonrasında ise SHGM'nin resmi sitesinde uçuşların başlatılacağı net bir tarih paylaşımı yapılmamıştır ancak uçuşların başladığı hatlar hakkında farklı uygulamalar varsa bunlar hakkında bilgilere yer verilmiştir. Devlet Hava Meydanları İşletmesi Genel Müdürlüğü'nün 2019 yılında yayınladığı sektör raporunda toplam yolcu sayısının \%1'inden fazla yolcu taşıyan Türkiye menşeili havayolları THY(Anadolujet, THY bünyesinde bulunduğu için ayrıca yer verilmemiş), Pegasus, Onur Air ve Sunexpress olduğu belirtilmiştir. Bu hava yollarından bazıları, hava yolu ulaşımı kısıtlaması sonrası farklı tarihlerde uçuşlara başlamıştır. İlk iç hat uçuşu 1 Haziran 2020 tarihinde THY tarafından yapılmıştır (Euronews, 2020b). THY ilk dış hat uçuşunu ise 18 Haziran 2020 tarihinde 14 Avrupa şehrine yapacağını THY basın müşaviri tarafından duyurmuştur (DW, 2021). Pegasus Hava Yolları ilk iç hat uçuşunu yine 1 Haziran'da, dış hat uçuşunu ise 13 Haziran'da yapacağını duyurmuştur (Pegasus Hava Yolları, 2021a). Anadolujet Hava Yolu 1 Haziran 2020'de iç hat, 11 Haziran 2020'de ise diş hat seferlerine yeniden başlayacağını duyurmuştur (Anadolujet, 2021). 25 Mart 2020'de Onur Air uçuşlarını askıya aldığını açıklamıştır (Cnnturk, 2020) ancak hala uçuşlara başlamadığı bilinmektedir. Bu durum, şirketin iflas ettiğine dair bir takım söylentilerin olduğu konusunun haberlere taşınmasına neden olmuştur (Airlinehaber, 2021). Sunexpress Hava Yolları 4 Haziran 2020'de 
iç hat, 10 Haziran 2020'de de dış hat uçuşlarına başlayacağını resmi sitesinden bildirmiştir. (Sunexpress, 2020).

Havacılık sektöründe uygulanan genel yasaklamalar ve izin verilen uçuşların da birçok tedbir altında gerçekleşmesi ve sonuç olarak yolcuların seyahat etmekten vazgeçmesi ve zorunlu haller dışında müşterilerin seyahatten kaçınması hava yolu şirketlerini oldukça zor günlerin beklediğini göstermektedir (Akca, 2020, s.47). Salgının kontrol altına alınması için uçuşların durdurulması havacılık sektörünü sekteye uğratarak sektörde büyük bir duraksamaya yol açmıştır. Erken dönemde yazılan bir makalede en iyi ihtimalin 2020 yaz sezonunda turizmin de canlanmasıyla uçuşların normale dönmesi iken kötü ihtimalin ise virüs yayılımının yeterince yavaşlamaması sonucu uçuşların eski haline dönmeden durumun belirsizliğinin devam etmesi olarak dile getirilmiştir. Bu durumun sonucunda hava yolu şirketleri açısından büyük bir gelir kaybı yaşanması ve şirketlerin finansal krizle karşı karşıya kalabilecekleri öngörüsünde bulunulmuştur (Macit ve Macit, 2020, s.113-114).

İGA (İstanbul Grand Airport) Genel Müdür Yardımcısı Mehmet Büyükkaytan salgından önce İstanbul havalimanında günde 1400 uçuş bulunduğunu salgında ise bu rakamın 40'a indiğini belirtmiştir (Süleyman Demirel Üniversitesi, 2021). Türk Hava Yolları'nın 2019'da yıllık geliri 13.229 milyon dolar iken 2020 yılında 6.734 milyon dolara düşmüştür. Yolcu sayısı ise 2019 'da 74,276 milyon iken 2020'de 27,950 milyona düşerek yolcu sayısında \%62,4 düşüş meydana gelmiştir. (Türk Hava Yolları, 2020). Pegasus Hava Yolları'nda ise yolcu sayıları 2019'da 30,76 milyondan 2020'de 14,71 milyona düşerek \%52,2'lik bir düşüş yaşamıştır (Pegasus Hava Yolları, 2021b). Sunexpress Hava Yolları'nın yıllık raporu veya yolcu sayılarına ilişkin bir rapor bulunamamıştır. Bunun nedeni Türk Hava Yolları ve Lufthansa Hava Yolları'nın ortaklığından oluşmuş bir şirket olması olabilir. Çünkü bu şirketlerin kendi yıllık raporları içerisinde Sunexpress Hava Yolları'nın sayılarına yer verilmiştir. Anadolujet'in de aynı şekilde verilerine ulaşılamamıştır ancak Türk Hava Yolları bünyesine bağlı bir şirket olduğu için THY'nin raporundaki sayılar Anadolujet'i de kapsamaktadır. Onur Air ise 2020'de uçuşların askıya alınmasından bu yana hiçbir uçuş yapmamış ve internet sitesini güncellemiştir. BBC Türkçe'de 5 Haziran 2020'de yapılan habere göre krizin tüm dünyada havacılık sektörünü olumsuz yönde etkileyeceği ancak Türkiye'de havacılık sektörünün rekabetçi ve esnek maliyeti yapısı gereği daha çabuk toparlanacağı ifade edilmiştir. Ayrıca THY'nin bu krizi kargo taşımacılığı ile dengeleyebileceği, Pegasus'un ise düşük maliyetli bir hava yolu şirketi olması nedeniyle bu tarz gelir dalgalanmalarını bertaraf etme kapasitesine sahip olduğu belirtilmiştir (BBC Türkçe, 2020). 


\section{COVID-19 SÜRECINDE HAVA YOLU ŞIRKETLERININ İLETIŞIMIM STRATEJILERİ}

Pandemi döneminde salgının daha fazla yayılmasını önlemek adına insanların temas etmemesi için çeşitli seyahat kısıtlamaları getirildi. Bu durum özellikle turizmi ve turizmden beslenen ulaşım, konaklama gibi diğer sektörleri sekteye uğrattı. Seyahat noktaları ve ulaşım şirketleri bu dönemde müşterilerine kendilerini unutturmamak için çeşitli iletişim stratejileri geliştirdiler. Kapanma dönemi ve açılma sonrası olmak üzere 2 dönemde ele alınan süreçte ülkelerin YouTube üzerinden verdikleri turizm tanıtımlarında farklı stratejiler izledikleri görülmüştür. Kapanma ve açılma döneminde 3 ana temaya vurgu yapıldığı görülmüştür. Kapanma döneminde ilham ve umut yaymak, insanlığın kardeşliği, son olarak özlem ve nostalji temaları ön plana çıkmıştır. Açılma döneminde ise tekrar merhaba, Covid-19 güvenli turizmi ve onarıcı deneyim kavramlarına yer verilmiştir (Ketter ve Avraham, 2021, s. 6-9).

Hava yolu yolcuları arasında hastalığın geçme riski tam olarak somutlaştırılmamış hatta anlaşılmamış olsa da yolcuların bu tehditten kaçındıkları görülmüştür. Uyumluluk, etki ve korku unsurları keyfi ve iş seyahatleri konusunda insanların tehdit hissetmesine sebep olan göstergelerdir (Lamb, Winter, Rice, vd. 2020, s. 6). İş amaçlı veya keyfi seyahat eden yolcuların Covid- 19 hakkında hissettikleri tehdidin ve korku seviyesinin artmasiyla seyahat etme isteklerinin azaldığı görülmüştür. Yıllık seyahat sıklığı fazla, dışa dönük ve risk alma eğilimi fazla olan insanlar ise iş seyahatlerine daha isteklidirler. Keyfi seyahat eden yolcuların risk alma eğilimi, sağlık sigortasından memnuniyeti, dışa dönüklük düzeyi ve duygulanım seviyesi arttıkça uçma istekleri de artmaktadır. Aynı zamanda uçma sebebi ne olursa olsun sağlık problemi olan kişilerin iş seyahatlerinden kaçındıkları gözlemlenmiştir (Diaconu, 2021, s. 236).

Covid-19; havayollarını, kaynaklarını sabit bir havayolu ile uçmayı önemsemeyen ya da kriz dönemi uçan müşterileri de kapsayan geniş bir müşteri kitlesine hitap ederek harcamaktansa sadık müşterilerine ayırmaya zorlamıştır. Yeni müşteri kazanmaktansa sadık müşterilerin kaldıraç olarak kullanılabilmesi havayolu açısından daha kolaydır. Sadık müşteri kitlesi hızlı bir şekilde canlandırılabilirse yeni müşteri kazanma maliyeti, var olan müşteriyi koruma karşısında bir anlam ifade etmemektedir. Amerikan Hava Yolları bu süreçte sadakat programındaki abonelik ücretleri gibi ücretleri kaldırmış ve sınıf atlama eşiğini düşürmüştür. Ayrıca anlaşmalı olduğu kredi kartları, oteller ve diğer şirketler aracılığıyla müşterilerine fırsatlar sunarak Covid-19 sürecinde pazarlama yönteminin çekirdeğini oluşturmuştur. Bilet parası iadesi yerine ise müşterilerine ekstra miller ve puanlar ile birlikte kredi kartları ile de kullanabilecekleri şekilde seyahat kredileri ödemelerinde bulunmuştur. Bu gibi kriz durumlarında sadakat programları havayolları için can simidi konumunda olduğu görülmektedir (Pascual ve Cain, 2021, s. 4-5). 
Pandemi süreci hava yolları açısından bir takım fırsatlar da doğurmuştur. İptaller, geri ödemeler, spesifik ve güncel bilgi alma açısından daha kolay olması nedeniyle insanların doğrudan markaya gitmeyi tercih etmeleri krizin olumlu sonuçlarındandır. Bu kriz iletişimi ve sosyal girişimler, şirketin imajını güçlendirebilir ve müşteri sadakatini sağlayabilir. Ayrıca, insan temasından kaçınmak için daha fazla dijitalleşme fırsatı sağlamıştır (Chevtaeva ve Guillet, 2021, s. 169-170).

\subsection{Türk Hava Yolu Şirketlerinin Dijital Pazarlama Stratejileri}

Işılar; Türk Hava Yolları (THY), Pegasus Hava Yolları ve üç yabancı hava yolunun dijital pazarlama stratejilerini karşılaştırdığı bir çalışmada pazarlama türlerini e-posta pazarlaması, web sitesi pazarlaması, mobil pazarlama, sosyal medya pazarlaması, arama motoru optimizasyonu, etkileyici pazarlaması ve oyunlaştırma tekniği olarak sıralamıştır. Türk Hava Yolları'nın ve Pegasus Hava Yolları'nın sayılan pazarlama tekniklerinden oyunlaştırma tekniği hariç tümünü kullandığı ortaya konmuştur (Işılar, 2021:59-60). THY Twitter hesabında en çok kurumsal, hizmet, haber ve satış teşvik, Pegasus'un ise satış teşvik ve kampanya konularında twit attığı görülmüştür. Twitter kullanımları daha çok satışı desteklemeye yönelik olduğu ve iletişim şeklinin bilgilendirmeye dayalı tek yönlü iletişim olduğu belirlenmiştir (Özgen ve Elmasoğlu, 2016, s. 193-199). Arabacı Koç (2020, s. 198) Covid 19 kapsamında THY'nin sosyal medyada kriz ve itibar yönetimini değerlendirmek amaciyla Youtube paylaşımlarını ele aldığı bir çalışma yapmıştır. Bu çalışmada kriz yönetiminde önemli olan ayırt edici özellikleri kullanarak THY'nin kurumsal itibarını, acıyı paylaşma ve anlayış stratejilerini, iyi reklam kampanyaları ve sosyal medya paylaşımları yoluyla koruduğu sonucuna ulaşmıştır. THY'nin pandemi dönemi Instagram gönderilerini bütünleşik afet iletişimi açısından incelendiği bir diğer çalışmada hijyen ve sosyal sorumluluk konularında yeterli paylaşımlarda bulunsa da ücret esnekliği ve sosyal mesafe konuları için yeterli paylaşım yapmadığı ortaya konmuştur (Erden Uzun, 2021, s. 467-468).

THY'nin resmi web sitesinde Facebook, Twitter, Youtube, Instagram ve Linkedin sosyal medya hesapları olduğu bilgisi bulunmaktadır. (THY, 2021). Pegasus Hava Yollarının ise Resmi internet sayfası altında bağlantı şeklinde kullanılan sosyal medya hesaplarının simgesi yer almaktadır. Bu sosyal medya mecraları Pegasus Blog, Facebook, Twitter, Youtube, Instagram ve Foursquare olarak siralanmaktadır (Pegasus Hava Yolları, 2021c).

\section{KÜLTÜREL BOYUTLARIN COVID-19 PANDEMİSINE ETKİSI}

Kültürel boyutlar farklı araştırmacılar tarafından farklı sınıflandırmalarla ortaya konmuştur. Toplumların kültürel farklılıklarını ifade eden bu boyutları Kluckhohn ve Strodtbeck, Schwartz, Hall ve Hofstede farklı konularda ortaya koymuştur. Hofstede 72 ülkeden 100 binden fazla kişiye uyguladığı anket ile toplumların farklı özelliklerini yansıtan dört farklı boyut olduğunu saptamıştır (Şekerli ve Gerede, 2011, s. 20). 
Kültürel boyutlar bu zamana kadar işletmeden iletişime birçok bilim dalının çalıştığı bir konu olmuştur. Bunun nedeni insanların içinde yaşadıkları toplumun kültürünü edinerek günlük yaşayışlarında ve karar verdikleri birçok konuda; kültürün taşıdığı özelliklerin bir sonucu olarak ortaya çıkan kültürel boyutlardan etkilenmeleridir (Lu, Rose vd., 1999; Mau, 2004).

Covid-19 küresel salgınının tüm toplumları aynı dönemde etkilemesi ve toplumların hastalığa ve tedbirlere farklı yaklaşması, kültürel boyutların pandemiye etkisinin ölçülmesi açısından çalışılmaya değer görülmüştür. Covid-19 pandemisi günlük yaşantıdaki davranış değişikliklerinin yanı sıra ekonomiyi de oldukça fazla etkilemiştir. Ancak ülke ve toplumsal bazda bakıldığında yapılan çalışmalar farklı kültürel özelliklerin, pandemiyi farklı şekillerde algıladığını ve farklı tepkiler verdiğini göstermektedir. Çok gelişmiş Avrupa ülkeleri içinde yüksek güç mesafesine sahip ülkelerde virüsün yayılımının düşük olduğu bulunmuştur. Bunun nedeni halkın otoriteden gelen talimatları uygulamaya istekli olmasıdır. Bireysellik boyutu yüksek olan toplumlarda virüsün yayılım hızı daha yüksektir. Çünkü kişisel özgürlükleri pahasına evde kalma ve toplanmalardan kaçınma gibi fedakârlıklara tahammül etme olasılığı daha düşüktür. Kolektif toplumlar ise toplumsal çıkarları bireysel çıkarlardan üstün tuttuğu için kısıtlamaları uygulama konusunda daha başarılıdır. Heveslilik boyutu daha yüksek olan toplumlarda ise bireylerin davranışlarını sosyal normlar aracılığıyla kontrol etmek daha zordur. Bu yüzden heveslilik boyutu yüksek olan toplumlarda devletin salgının yayılmasını önlemek amacıyla koyduğu kısıtlayıcı tedbirlerin uygulanması güçleşmektedir (Gokmen, Baskici ve Ercil, 2021, s. 7).

Covid-19 döneminde insanların yatırım hareketleri de kültürel boyutlardan etkilenmiştir. Örneğin borsa hareketliliğine bakıldığında kolektif ve yüksek belirsizlikten kaçınan toplumların bireysel ve düşük belirsizlikten kaçınan toplumlara göre daha olumsuz tepki verdiği ve daha fazla dalgalanmaya sebep oldukları görülmüştür (Fernandez-Perez, Gilbert, vd. 2021, s. 9). Ayrıca yatırımcılar ne kadar çok belirsizlikten kaçınırsa teyit edilmiş yüzde birlik büyümenin bile hisse senedi getirilerinde o oranda yüksek düşüşe yol açtığ olduğu bulunmuştur (Ashraf, 2021, s. 12). Kolektif ve yüksek belirsizlikten kaçınan toplumların ekonomik olarak korumacı davrandıkları ve bir nebze panikle hareket ettikleri görülmektedir. Bu davranış şekli uçakla seyahat söz konusu olduğunda eğer zaruri bir seyahat değilse (ülkeye, eve dönmek, vs.) bilet değişikliği, iptali ya da uçuştan vazgeçmek gibi davranışlara yol açabileceğini göstermektedir.

ABD genelinde 3.141 kişi, 29 ülkeden 367,109 kişi ve 67 ülkeden 277.219 kişiyle yapılan görüşmelerde kolektiflik ile maske kullanımı arasındaki ilişkiye bakıldığında çalışmanın üçayağında da kolektif boyutun maske kullanımını olumlu yönde etkilediği bulunmuştur. Bunun nedeni olarak da kolektif toplumlarda insanların akraba, arkadaş gibi sosyal çevresinin geniş olması ve onların hastalığa yakalanmasını istememesidir. Çalışma sonucunda küresel krizler karşısında kolektivizmin etkisine vurgu yapılmıştır (Lu, Jin, ve English, 2021, s. 3-5,6). 
131 ülke ve münferit ilçelerdeki birkaç hafta geriye dönük şekilde Google'dan geri izleme yöntemiyle elde edilen verilerin toplandığı bir çalışmada yüksek belirsizlikten kaçınma oranına sahip olan ülkelerde marketler, parklar, istasyonlar, iş yerleri gibi ortak alanlarda bulunma oranı daha düşük çıkmıştır. İlginç bir şekilde yüksek bireyselliğe sahip ülke vatandaşlarının park alanlarında daha fazla bulundukları tespit edilmiştir (Huynh 2020, s. 11,16). 73 ülkeden elde edilen verilerde uzun vadelilik boyutunun 1 puan bile daha yüksek olduğu toplumlarda ölüm ihtimal ve oranlarının daha yüksek olduğu bulunmuştur. Bu durum akut kriz durumlarında kısa vadeli veya acil durumlara daha fazla vurgu yapılmasının faydalı olduğunu kanıtlayabilmektedir. Kısa vadeliliği tercih eden ülkeler şimdiye daha fazla odaklanılmasını, acil tedbirlere daha sıkı uyulmasını, krizlere daha hızlı yanıt verilmesini ve talimatlara daha fazla uyulmasını sağlayabilmektedir. Yüksek belirsizlikten kaçınma boyutu, ölümcül sonuç ihtimalinin ve ölüm riskinin artması ile ilişkilendirilmiştir. Yüksek belirsizlikten kaçınan toplumların değişime kapalı ve bürokratik işlerinin fazla olması gibi özellikleri nedeniyle daha zayıf sosyal tepkiler vermesi, etkisiz iletişim stratejileri kullanması ve hassas gruplara daha az ilgi göstermesi gibi faktörlerle bu toplumlarda krizin daha kötüleştiği görülmüştür. Heveslilik boyutu yükseldikçe ise toplumun genelinde ölüm riskinin arttığı görülmüştür. Bu durum heveslilik boyutunda insanların daha dışa dönük olması ve katı sosyal kurallara uymamasına bağlanabilir. Bireyselliğin yüksek olduğu toplumlarda enfekte kişilerin ölüm oranı yüksek çıkmıştır; bu hastalığa yakalanan bireylerin genellikle daha savunmasız alt gruplardan (yaşlılar gibi) olduğu ve bu grupların bakımında kurumsal desteğe güvenildiğini işaret etmektedir (Erman ve Medeiros, 2021, s. 14-16). Toplumda bireysellik arttıkça hastalığa yakalanmanın ve ölümün arttığı, kolektivizm arttıkça toplumun sağlığı ve toplumsal çıkarlar için Covid-19'dan korunma talimat ve kurallarına gönüllü bir şekilde uyulduğu gözlemlenmiştir (Maaravi, Levy, vd., 2021, s. 4-6).

\section{4. ÇALIŞMANIN METADOLOJİSI}

THY ve Pegasus'un yarı yarıya bir müşteri kaybı yaşansa da uçuşlara dönmesi ve tedbirlerini duyurarak müşterilerine bilgilendirmede bulunması BBC Türkçe (2020)'nin finansal krize rağmen uçuşlara döndüğü haberini doğrular niteliktedir. Sunexpress ve Anadolujet gibi iştirak kuruluş olan hava yolu şirketleri bağlı bulundukları kurumun çatısı altında değerlendirildiği için pandemi sürecinden nasıl etkilendiklerine dair somut veriler elde edilememiştir. Onur Air'in ise krizi henüz atlatamadığı ve akıbetinin belirsizliğini koruduğu görülmektedir. Bu nedenlerden dolayı sadece THY ve Pegasus Hava Yollarının geçerli verilerine ulaşılmıştır. Kaynak taraması esnasında THY ile ilgili çok sayıda çalışma yapıldığı görülmüştür ancak Pegasus Hava Yolu ile ilgili çok fazla çalışmaya rastlanmamıştır. Literatürdeki bu eksikliği azaltmak adına çalışma Pegasus Hava Yolları'nı ele alacaktır.

Sabiha Gökçen Havalimanı'ndan yapılan tüm uçuşlar 27 Mart 2020 tarihi itibariyle durdurulmuştur (Pegasus, 2020a). Ana meydan olarak Sabiha Gökçen Havalimanı'nı kullanan 
Pegasus bu kararla beraber uçuşlarını durdurmuştur. 1 Haziran 2020'de iç hat, 13 Haziran 2020'de ise dış hat uçuşlarına başlamıştır (Pegasus, 2020b-c). Çalışmanın verileri yukarıda verilen tarih aralığından alınacaktır. Bu bilgiler ışığında çalışmanın evrenini pandemi başlangıcından itibaren günümüze uzanan zaman aralığında Türk hava yolu şirketlerinin sosyal medya paylaşımları oluşturmaktadır. Örneklemi ise amaçlı örneklem yöntemiyle seçilmiştir. 27 Mart- 13 Haziran 2020 tarih aralığında Pegasus Hava Yolları'nın Instagram hesabından yaptığı paylaşımlardan oluşmaktadır.

Veriler Instagram sosyal medya hesabında yer alan görsel dökümanlardan oluşmaktadır. Diğer sosyal medya mecralarından yapılan paylaşımlarda anlamlı bir veri elde edilememiştir.

Çalışma yöntemi ise nitel bir yöntem olan içerik analizidir. Fotoğraflarda, kültürel boyutları ifade edebilecek temalar aranmış ve bulunan temalar nicelleştirilerek bulguların geçerliliği sağlanmaya çalışılmıştır.

Türkiye toplumunun kültürel boyutlarına bakıldığında güç aralığının ve belirsizlikten kaçınmanın yüksek olduğu görülmektedir. Erillik-Dişillik boyutu birbirine yakın olmakla beraber dişillik biraz daha yüksektir. Bireysellik-Kolektiflik boyutunda ise kolektif özelliğin ağır bastığı söylenebilir. Uzun Vade Odaklılık ve Heveslilik boyutları ise ortalamaya oldukça yakındır. Şekil 1'de Türkiye toplumunun kültürel boyutlarına ait sayısal değerler paylaşılmıştır (Hofstede, 2021).

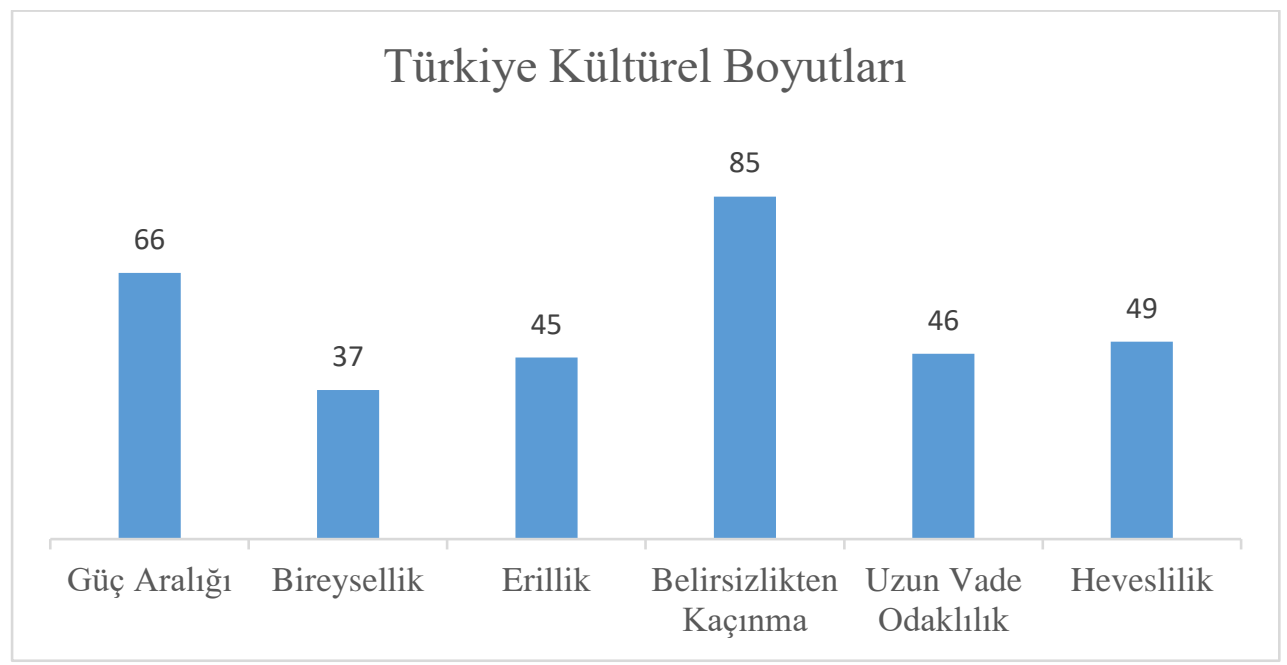

Şekil 1: Türkiye Kültürel Boyutları (Hofstede, 2021)

Yapılan çalışmalarda Dişillik-Erillik boyutu ile ilgili anlamlı veriler elde edilemediği için bu boyut çalışma dışı bırakılmıştır. Heveslilik-Kısıtlılık ve Uzun Vade Odaklılık-Kısa Vade Odaklılık boyutları toplumda ortalama seviyede olduğu için bu boyutlar da çalışmaya dâhil edilmemiştir. 


\section{1. Çalışmanın Amacı ve Varsayımları}

Pegasus Hava Yolları Türkiye menşeili bir şirkettir ve müşteri kitlesini genellikle Türkiye vatandaşları oluşturmaktadır. Bu nedenle Instagram sayfası Türkçedir. Ülkelerin kültürel farklılıkları tüketici davranışları arasında belirgin bir farka sebep olur. Müşterilerin bireysel ve sosyal tercihleri de doğrudan kültürden etkilenmektedir. Kültürün tüketim davranışı üzerindeki bu derin etkisi nedeniyle pazarlama bu kültürel özellikler üzerinden planlanır (Saydan ve Kanıbir, 2007, s. 86). Şirketlerin müşteri kitlesini kültürel olarak tanıması pazarlama için en gerekli unsurlardan biridir. Bu noktadan yola çıarak Pegasus Hava Yolları'nın paylaşım yaparken kültürel özelliklere hitap eden paylaşımlar yapmayı tercih etmesi gerektiği söylenebilir. Çalışmada amaç; Türkiye kültürel boyutlarının, hava yolu şirketi tarafından paylaşılan gönderilerde kendisini ne kadar gösterdiğini bulmaktır. Böylelikle hava yolu şirketinin iletişim stratejisi doğrultusunda yaptığı paylaşımların hitap ettiği kitlenin kültürüne uygun olup olmadığı anlaşılacaktır. Bu bağlamda yapılan paylaşımlar ile ilgili şu varsayımlar yapılabilir:

H:1- Türk toplumuna ait güç aralığı kültürel boyutu toplumda yüksek olduğu için Pegasus Hava Yolları, gönderilerinde kuralları yazılı olarak sunmaktadır otoritelere ve kurallardan bahsederken yetkili kurumlara atıfta bulunmaktadır.

H:2- Pegasus Hava Yolları Instagram sosyal ağındaki paylaşımlarda aile ve sevdiklerimizi korumak için toplumsal çıkarlardan bahsedilerek tedbirlere uyulması için kolektiflik vurgusu yapmaktadır.

H:3- Türk toplumu yüksek belirsizlikten kaçınma boyutu yüksek olan bir toplum olduğu için bilgilendirmelerin zamanında net bir şekilde yapılması gerekmektedir. Bu nedenle Pegasus Hava Yolları paylaşımlarında sosyal mesafe kurallarına ve gerekli hijyen tedbirlerine vurgu yapmaktadır. Ekonomik belirsizliği ortadan kaldırmak için ise iptal olan uçuşlar hakkında para iadesi ve bilet değişikliği konularında teminat vermektedir.

\subsection{Araştırma Soruları}

Yukarıdaki varsayımlardan hareketle araştırmanın sorularını şunlar oluşturmaktadır:

1. Paylaşımlarda Sağlık Bakanlığı, Sivil Havacılık Genel Müdürlüğü, Havalimanı ve Havayolu Yönetimi ve Yöneticileri gibi otorite isim ve söylemlerine yer verilmiş midir?

2. Paylaşımlarda kurallara yazılı olarak yer verilmiş midir?

3. Paylaşımlarda aile, arkadaşlık, dostluk gibi temalara yer verilmiş midir?

4. Paylaşımlarda toplum sağlı̆̆ına yer verilmiş midir?

5. Paylaşımlarda sosyal mesafe, hijyen ve maske kullanımı konularına yer verilmiş midir? 
6. Paylaşımlar doğrudan bilgi paylaşımı amacıyla tekli gönderi şeklinde mi yoksa bilgilerin dağılma ve görülmeme ihtimali olan çoklu gönderi şeklinde mi paylaşılmıştır?

7. Uçuşların durdurulması ve yeniden başlatılması gibi önemli bilgiler önceden paylaşılmış mıdır?

8. Bilet değişikliği ve iadesi gibi ekonomik konularda net bilgiler paylaşılmış mıdır?

\subsection{Verilerin İncelenmesi}

Belirtilen tarih aralığında toplamda 33 gönderi bulunmaktadır. Bunlardan 23 tanesi pandemi sürecine ilişkindir. Bu gönderilerin biçimsel analizi ve paylaşım konuları Tablo-1'de yer almaktadır.

Tablo 1: Pegasus Hava Yolları Instagram Gönderilerinin Analizi

\begin{tabular}{|c|c|c|c|c|c|c|c|c|c|}
\hline Özellikler & $\frac{8}{i \frac{\pi}{\infty}}$ & 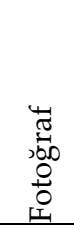 & 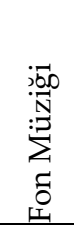 & $\begin{array}{l}\text { N } \\
\text { 员 } \\
\omega^{2}\end{array}$ & 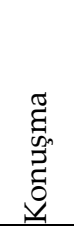 & 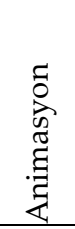 & 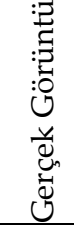 & 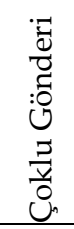 & 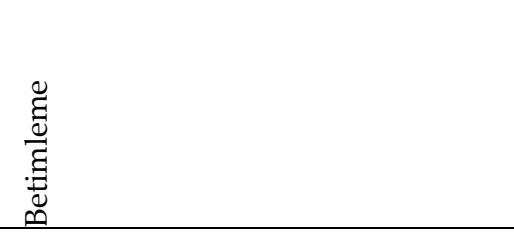 \\
\hline 30 Mart 2020 & $x$ & & & $x$ & & $x$ & & & Açığa alınan, iptal biletler \\
\hline 2 Nisan 2020 & $x$ & & $x$ & & & $x$ & $x$ & & Uçuşlara ara verme- özlem \\
\hline 13 Nisan 2020 & $x$ & & & $x$ & & $\mathrm{x}$ & $x$ & & $\begin{array}{l}\text { Flypgs.com sitesinde duyuru ve } \\
\text { bilgilendirmeler }\end{array}$ \\
\hline 2 Mayıs 2020 & $x$ & & $\mathrm{x}$ & & $\mathrm{x}$ & $x$ & $x$ & & $\begin{array}{l}\text { Yakında Güzel Günler, Özlem, } \\
\text { Kavuşma }\end{array}$ \\
\hline 11 Mayıs 2020 & & $x$ & & $x$ & & $\mathrm{x}$ & $x$ & $x$ & Covid-19 Bilgilendirme \\
\hline 14 Mayıs 2020 & & $\mathrm{x}$ & & $x$ & & $\mathrm{x}$ & & $x$ & Kabin Havası-Hepa Filtre \\
\hline 16 Mayıs 2020 & $x$ & & & $x$ & & $x$ & & & Kabin Havası-Hepa Filtre \\
\hline 20 Mayıs 2020 & $x$ & & $\mathrm{x}$ & & & $x$ & & & $\begin{array}{l}\text { Ekiplerin aldığı önlemler- koruyucu } \\
\text { donanım }\end{array}$ \\
\hline 22 Mayıs 2020 & & $x$ & & $x$ & & $x$ & & $x$ & HES kodu zorunluluğu \\
\hline 23 Mayıs 2020 & $x$ & & $x$ & & & $\mathrm{x}$ & & & $\begin{array}{l}\text { Yolcuların tabi olduğu kurallar ve } \\
\text { önlemler }\end{array}$ \\
\hline 29 Mayıs 2020 & & $\mathrm{x}$ & & $\mathrm{x}$ & & $\mathrm{x}$ & & & $\begin{array}{l}\text { Yolcuların tabi olduğu kurallar ve } \\
\text { önlemler }\end{array}$ \\
\hline 30 Mayıs 2020 & & $x$ & & $x$ & & $x$ & $x$ & & Yurt içi uçuşların başladığı bilgisi \\
\hline 30 Mayıs 2020 & $x$ & & $\mathrm{x}$ & & & $x$ & $x$ & & Yurt içi uçuşların başladığı bilgisi \\
\hline 1 Haziran 2020 & $x$ & $x$ & & $x$ & & & $x$ & $x$ & İlk uçuşu yapan ekip ve uçak \\
\hline 2 Haziran 2020 & $x$ & & $\mathrm{x}$ & & & $x$ & & & $\begin{array}{l}\text { Uçakların temizlenmesi- Teması } \\
\text { azaltacak tedbirler }\end{array}$ \\
\hline 3 Haziran 2020 & & $x$ & & $x$ & & $x$ & & & Maske takma zorunluluğu \\
\hline 3 Haziran 2020 & & $x$ & & $x$ & & $x$ & & & Yurtiçi gidilecek meydanlar \\
\hline 4 Haziran 2020 & & $x$ & & $x$ & & $x$ & & & Uçak içine bagaj alınmaması \\
\hline 8 Haziran 2020 & $x$ & & & $x$ & & $x$ & & & $\begin{array}{l}\text { Uçak içi eğlenceye elektronik } \\
\text { aletlerden ulaşım- Teması azaltacak } \\
\text { tedbirler }\end{array}$ \\
\hline 9 Haziran 2020 & & $\mathrm{x}$ & & $\mathrm{x}$ & & $\mathrm{x}$ & & & $\begin{array}{l}\text { Yolcuların tabi olduğu kurallar ve } \\
\text { önlemler }\end{array}$ \\
\hline
\end{tabular}




\begin{tabular}{|l|l|l|l|l|l|l|l|l|l|}
\hline 10 Haziran 2020 & & X & & X & & X & & & Almanya uçuşlarının başlaması \\
\hline 11 Haziran 2020 & & X & & X & & X & & & Avrupa uçuşlarının başlaması \\
\hline 12 Haziran 2020 & X & & & & X & & X & & Covid-19 sonrası alınan önlemler \\
\hline TOPLAM & 12 & 12 & 6 & 16 & 2 & 21 & 8 & 4 & 23 Paylaşım \\
\hline
\end{tabular}

Pegasus Hava Yollarına Instagram hesabında paylaşılan iletilerde bir kez iptal olan uçuşlar, üç kez duygusallık ve özlem, bir kez internet sitesine yönlendirme, altı kez şirketin kendi aldığ1 tedbirler, sekiz kez yolcular için genel kurallar ve tedbirler, dört kez uçuşa başlama konularına değinerek toplamda 6 farklı konuda paylaşımda bulunulmuştur. $\mathrm{Bu}$ paylaşımların biçimsel özellikleri ve içerikleri dikkate alındığında, elde edilen temalar ve işaret ettikleri kültürel boyutlar aşağıdaki Tablo-2' de gösterilmiştir.

Tablo 2: Kültürel Boyutları İfade Eden Temaların Analizi

\begin{tabular}{|c|c|c|c|c|}
\hline Kültürel Boyutlar & $\begin{array}{l}\text { Vurgulanan } \\
\text { Temalar }\end{array}$ & $\begin{array}{l}\text { Yüksek Güç } \\
\text { Aralığının } \\
\text { Vurgulandığı } \\
\text { Gönderi Sayısı }\end{array}$ & $\begin{array}{l}\text { Yüksek } \\
\text { Belirsizlikten } \\
\text { Kaçınmanın } \\
\text { Vurgulandığı } \\
\text { Gönderi } \\
\text { Sayısı } \\
\end{array}$ & $\begin{array}{l}\text { Kolektifliğin } \\
\text { Vurgulandığ1 } \\
\text { Gönderi Sayısı }\end{array}$ \\
\hline $\begin{array}{l}\text { Yüksek } \\
\text { Güç Aralığı }\end{array}$ & $\begin{array}{l}\text { Otoriteler } \\
\text { Yazılı kurallar }\end{array}$ & $\begin{array}{l}4 \\
8 \\
\end{array}$ & & \\
\hline $\begin{array}{l}\text { Yüksek Belirsizlikten } \\
\text { Kaçınma }\end{array}$ & $\begin{array}{l}\text { Yazılı bilgi } \\
\text { Tek gönderi } \\
\text { Uçuşların } \\
\text { durdurulması } \\
\text { Uçuşların } \\
\text { başlatılması } \\
\text { Bilet değişikliği- } \\
\text { iadesi }\end{array}$ & & $\begin{array}{c}20 \\
19 \\
0 \\
4 \\
4 \\
2\end{array}$ & \\
\hline Kolektiflik & $\begin{array}{l}\text { Aile, dostluk } \\
\text { Toplum sağllğ } 1 \\
\end{array}$ & & & $\begin{array}{l}2 \\
6 \\
\end{array}$ \\
\hline & Toplam & 12 & 57 & 8 \\
\hline
\end{tabular}

Paylaşımlara bakıldığında belirtilen tarih aralığında 33 gönderi paylaşımı yapıldığı görülmektedir. Bunlardan 23 tanesi pandemi hakkında yapılan paylaşımlardır. Çalışma 23 gönderi üzerinden ilerleyecektir. 23 gönderinin sadece 4 tanesi çoklu gönderi olup kalan 19 gönderi tek içerikten oluşmaktadır. Bu durum doğrudan bilgi paylaşımının tercih edildiğini ve yüksek belirsizlikten kaçınma boyutuna hitap edildiğini göstermektedir.

Hesapta 12 video, 12 fotoğraf gönderisi bulunmaktadır. 23 gönderinin 21 tanesinde animasyon kullanılmıştır. Animasyonların kullanımı sayesinde yazılı kural ve bilgi paylaşımı yapılması sağlanmıştır. İşitilen bilgilerin eksik ya da yanlış anlaşılma riskine karşılık videoların sadece 2 tanesinde sözlü iletişime yer verilmiştir. Yazılı kuralların kullanımına 8 kez rastlanılmıştır ve bu durum yüksek güç aralığı boyutuna işaret etmektedir. Otorite kullanımı olarak ise bir gönderide şirketin Genel Müdürü; Sağlık Bakanlığı, Ulaştırma Bakanlığı ve Bilim Kurulu öneri ve talimatlarına yer vererek açılama yapmıştır. Ayrıca başka 
bir gönderide yine Sağlık Bakanlığı'na atıfta bulunulmuştur. Bu veriler yüksek güç aralığı boyutunun tercih edildiğini göstermektedir.

Yazılı bilgi paylaşımı ise 20 gönderide yapılmıştır. $\mathrm{Bu}$ da belirsizlikten kaçınma boyutuna dikkat edildiğini göstermektedir. Sosyal mesafe, maske ve hijyen temalarına $12 \mathrm{kez}$ yer verilmiştir. Hem yolcular hem de çalışanlar için bu temalar kullanılmıştır. 23 gönderinin 19 tanesi tek gönderidir. Çoklu gönderiler yan tarafa kaydırma gerektirdiği için kimi zaman fark edilmemekte kimi zaman ise bilinçli olarak yanda bulunan gönderilere bakılmamaktadır. Bu durum bilgi aktarımında eksikliğe yol açabilir. Dolayısıyla gönderinin tek olması bilginin alıcıya direkt ulaşmasını çoklu gönderiye göre daha fazla sağlar. Tek gönderi paylaşımı bilginin alıcıya ulaşıp ulaşmadığı belirsizliğini ortadan kaldıran bir durumdur. Uçuşların durdurulması hakkında net bir bilgi paylaşımına rastlanılmamıştır Ancak başlatılacağı tarih öncesinde başlayacağı zaman, hatlar, kurallar hakkında bolca bilgi paylaşımına yer verilmiştir. Uçuşların başlatılacağı süreç hakkında 4 tane paylaşımda bulunulmuştur. Ancak uçuşların ne zaman durdurulduğu hakkında bir paylaşımda bulunulmamıştır. Bu belirsiz süreç bir çeşit kriz dönemine dönüşmüştür ve hava yollarının nasıl bir tepki vereceği konusunda kararsız kaldığını göstermektedir. Uçuşların durdurulması akabinde belirsizliğe yer vermeden bilet değişikliği ve iptali konusunda 2 tane gönderi paylaşılmıştır. Uçuşların durdurulmasını konusu hariç diğer tüm konularda net ve dakik bir şekilde bilgi paylaşımı yapılmıştır. Bu veriler yüksek belirsizlikten kaçınma boyutunun tercih edildiğini göstermektedir.

Kolektiflik vurgusu ise aile, dostluk, arkadaşlık akraba gibi kavramlar ile toplum sağlığını korumak için kişisel tedbirlere değinilmesi beklenmektedir. Aile ve dostluk temasına 2 kez toplum sağlığ vurgusuna ise 4 kez değinildiği bulunmuştur. 23 gönderide toplamda 6 kez kolektiflik vurgusu yapıldığı görülmektedir. "Toplum ve sevdiklerimizin sağlığını önemsiyorsak tedbirlere daha sıkı uymalıyı" vurgusunu yapabilmek için aile ve dostluk temasina daha fazla vurgu yapılması beklenmektedir.

\section{SONUÇ}

Hava yolları pandemiden etkilenen ilk sektörler arasındadır. Teması azaltmak için ilk başvurulan uygulama uçuşları askıya almak olmuştur. Uçuşların yeniden başlama tarihindeki belirsizlik hem hava yolları hem de yolcular açısından kaygılı bir sürece dönüşmüştür. Bu süreçte hava yolları yolcuları ile iletişimi aktif tutarak müşteri sadakatini kaybetmemek üzerine yoğunlaşmıştır. Bu iletişimi de en kolay şekilde sosyal medya araçlarından yürütmektedir. Hava yolu şirketinin müşteri kitlesini tanıması ve onun kültürel kodlarına uygun paylaşımlarda bulunması yolcularıyla olumlu şekilde iletişimini sürdürmesi için en önemli stratejilerden biridir. Ayrıca pandemi sürecine farklı toplumlardan farklı yaklaşımlar gelmesi ve kurallara uyma konusunda farklı davranışlar sergilemesi kültürel boyutlardaki farklılığın önemini bir kez daha ortaya koymuştur. Kültürel boyutların pandemi sürecine 
etkisi ve şirketlerin iletişim stratejini müşteri kitlesinin kültürüne göre belirleme gerekliliği çalışmanın kültürel boyutlar kuramı üzerinden kurgulanmasını gerektirmiştir.

Çalışmaya konu olan Pegasus Hava Yolları'nın yukarıdaki anlatılan nedenlerden dolayı pandemi süreci ile ilgili yaptığı bilgilendirme paylaşımlarında Türkiye Kültürel Boyutları'na uygun paylaşımlar yapması beklenmiştir. Belirli tarih aralığından elde edilen Instagram gönderileri içerik analizine tabi tutulduğunda yüksek güç aralığı boyutunun 12 kez, yüksek belirsizlikten kaçınma boyutunun $57 \mathrm{kez}$ ve kolektiflik boyutunun 8 kez vurgulandığ görülmüştür. Türkiye kültürel boyutlarına bakıldığında yüzdesel olarak güç aralığının 66, belirsizlikten kaçınmanın 85 kolektifliğin 63 olduğu görülmektedir. Sayısal değerler arasında pozitif ilişki olduğu görülmektedir. Buna rağmen güç aralığı ve kolektiflik vurgusu bir miktar daha fazla olması beklenmektedir. Çünkü bu iki boyutun pandemi ile mücadelede etkin bir rol oynadığı yapılan çalışmalarda ortaya konmuştur. Otoritelerin ve yazılı kuralların paylaşımlarda daha fazla yer alması daha güçlü bir etki yaratabileceği ve yüksek güç aralığı toplumla örtüştüğü için kitle tarafından kabul görebileceği düşünülmektedir. Ayrıca aile ve dostluk teması ve toplum sağlı̆ 1 temasının daha fazla yer alması yine toplumla örtüşen bir boyutu işaret etmesi sebebiyle kurallara daha fazla uyulması yönünde olumlu etkide bulunabileceği düşünülmektedir. Yüksek belirsizlikten kaçınma boyutu; pandemi ile mücadelede olumsuz bir ilişkide olmasına rağmen iletişim stratejisinde kullanılması gereken bir boyuttur. Bu olumsuz ilişki toplumun yeni şartlara uyum sağlayamamasını ifade etmektedir. Ancak iletişim stratejilerinde özellikle hedef kitlenin yüksek belirsizlikten kaçınma özelliği göstermesi, bu son derece belirsiz olan süreçte bazı konuların netliğe kavuşması gerekliliğini doğurur. Bu konuda ise Pegasus Hava Yolu oldukça bilgilendirici ve açık paylaşımlarda bulunmuştur. Temalarda rastlanma sayısı da bunu açıkça göstermektedir.

Pegasus Hava Yolları pandemi sürecinde büyük ölçüde Türkiye'nin kültürel boyutları ile örtüşen şekilde paylaşımlar yapmıştır. Çalışmanın sonucunda çalışma varsayımları doğrulanmıştır. Ayrıca kültürel boyutların havayolu şirketlerinin Covid-19 döneminde yapılan kriz iletişim stratejilerinin belirlenmesinde de rol oynadığı söylenebilir. Çalışma başka hava yolu şirketleri üzerinden daha uzun dönemleri içeren verilerle genişletilebilir. Ayrıca başka ülkeler ve ülkelere ait hava yolları ile karşılaştırma çalışmaları da kültürel boyutlar kuramının kriz dönemlerinde iletişim stratejileri açısından önemini ortaya koyabilir. Yapılan bu çalışma gelecek çalışmalara kısa bir ön gösterim sunmaktadır. 


\section{KAYNAKÇA}

Akca, M. (2020). Covıd-19'un Havacılık Sektörüne Etkisi. Avrasya Sosyal ve Ekonomi Araştırmaları Dergisi, 7(5), 4564.

Arabacı Koç, M. (2020). Covıd-19 Salgınının Yarattığı Küresel Kriz Bağlamında Sosyal Medyada Kriz Yönetimi: Türk Hava Yolları Örneği. Avrasya Sosyal ve Ekonomi Araştırmaları Dergisi, 7, 190-200.

Ashraf, B. N. (2021). Stock Markets' Reaction to COVID-19: Moderating Role of National Culture. Finance Research Letters, 41, 101857.

Chevtaeva, E., \& Guillet, B. D. (2021). A Review Of Communication Trends Due to the Pandemic: Perspective From Airlines. Anatolia, 32(1), 168-171.

Diaconu, L. (2021). The Behaviour of Airlines' Passengers in The Context of COVID-19 Pandemic. CES Working Papers, 13(2), 230-242.

Erden Uzun, C. (2021). Covid-19 Pandemi Sürecinde Türk Hava Yolları'nın Sosyal Medya İletişim Stratejileri. B. Pazarbaşı, S. Koç Akgül (Ed.) İletişim Bilimleri Bakış Açısıyla Küresel Afet Covid-19 Pandemisi içinde (451470). Hiper Yayın.

Erman, A., \& Medeiros, M. (2021). Exploring The Effect of Collective Cultural Attributes on COVID-19-Related Public Health Outcomes. Frontiers in Psychology, 12, 884.

Fernandez-Perez, A., Gilbert, A., Indriawan, I., \& Nguyen, N. H. (2021). COVID-19 Pandemic and Stock Market Response: A Culture Effect. Journal of Behavioral and Experimental Finance, 29, 100454.

Gokmen, Y., Baskici, C., \& Ercil, Y. (2021). The impact of national culture on the increase of COVID-19: A crosscountry analysis of European countries. International Journal of Intercultural Relations, 81, 1-8. doi:10.1016/j.ijintrel.2020.12.00.

Huynh TLD. Does Culture Matter Social Distancing Under The COVID-19 Pandemic? Saf Sci. 2020 Oct;130:104872. doi: 10.1016/jma.ssci.2020.104872.

Işılar, H. B. (2021). Havayolu Endüstrisinde Dijital Pazarlama Uygulamalarının Değerlendirilmesi. Havacılık ve Uzay Çalışmaları Dergisi, Vol.1, no. 2, 42-63.

Ketter, E., \& Avraham, E. (2021). \# StayHome today so we can\# TravelTomorrow: Tourism Destinations' Digital Marketing Strategies During the Covid-19 Pandemic. Journal of Travel E Tourism Marketing, 1-14.

Lamb, T. L., Winter, S. R., Rice, S., Ruskin, K. J., \& Vaughn, A. (2020). Factors That Predict Passengers Willingness to Fly During and After The COVID-19 Pandemic. Journal of Air Transport Management, 89, 101897:1-10.

Lu, J. G., Jin, P., \& English, A. S. (2021). Collectivism Predicts Mask Use During COVID-19. Proceedings of the National Academy of Sciences, 118(23):1-8.

Lu, L. C., Rose, G. M., \& Blodgett, J. G. (1999). The Effects of Cultural Dimensions on Ethical Decision Making in Marketing: An Exploratory Study. Journal Of Business Ethics, 18(1), 91-105.

Maaravi, Y., Levy, A., Gur, T., Confino, D., \& Segal, S. (2021). “The Tragedy of The Commons": How Individualism and Collectivism Affected The Spread of the COVID-19 Pandemic. Frontiers in Public Health, 9, 37.

Macit, A. \& Macit, D., (2020). Management of Covid-19 Pandemic in Turkısh Civil Avıatıon Sector. Avrasya Sosyal ve Ekonomi Araştırmaları Dergisi, 7(4), 100-116. 
Mau, W. C. J. (2004). Cultural Dimensions of Career Decision-Making Difficulties. The Career Development Quarterly, $53(1), 67-77$.

Pascual, M. E., \& Cain, L. N. (2021). Loyalty Programs: The Vital Safety Feature for Airlines to Survive COVID-19. International Hospitality Review.

Saydan, R., \& Kanıbir, H. (2007). Global Pazarlamada Toplumsal Kültür Farklılıklarının Önemi. Elektronik Sosyal Bilimler Dergisi, 6(22), 74-89.

Şekerli, E. B. \& Gerede, E. (2011). Kültürün EKY'ye Etkileri ve Türk Pilotların Hofstede Kültür Boyutları Açısından Durumları. "İ̧̧, GÜÇ" Endüstri İlişkileri ve İnsan Kaynakları Dergisi, 13(1), 17-38.

Özgen, Ö. \& Elmasoğlu, K. (2016). Sosyal Medya ve Marka İletişimi: Havayolu Şirketlerinin Twitter Kullanımına Yönelik Bir Araştırma. İletişim Kuram ve Araştırma Dergisi, no. 43, 181-202.

Airlinehaber, 2021. https://www.airlinehaber.com/onur-air-iflas-mi-etti/ (15.05.2021)

Anadolujet, 2021. https://www.anadolujet.com/tr/kurumsal/haberler-ve-duyurular/yurt-disi-seferlerimiz-yenidenbasliyor (15.05.2021)

BBC Türkçe, 5 Haziran 2020. https://www.bbc.com/turkce/haberler-turkiye-52927751 (29.05.2021)

CNNTURK, 2020. https://www.cnnturk.com/turkiye/koronovirusu-nedeniyle-onur-air-ucuslarini-askiya-aldi $(15.05 .2021)$

Sağlık Bakanlığı Resmi İnternet Sitesi. COVID-19 Bilgilendirme Platformu. Pandemi. https://covid19.saglik.gov.tr/TR-

66494/pandemi.html\#: :text=Bir\%20hastal\%C4\%B1\%C4\%9F\%C4\%B1n\%20veya\%20enfeksiyon\%20etkeni nin,DS\%C3\%96)\%20taraf\%C4\%B1ndan\%20pandemi\%20ilan\%20edilmi\%C5\%9Ftir. (02.07.2020).

SHGM, 2021. http://web.shgm.gov.tr/tr/genel-duyurular (13.05.2021)

DHMI, 2021. $\quad$ https://www.dhmi.gov.tr/Lists/HavaYoluSektorRaporlari/Attachments/13/ 2019\%20Havayolu\%20Sekt\%C3\%B6r\%20Raporu.pdf (13.05.2020)

DW, 2021. https://p.dw.com/p/3d8YF?maca=tr-Whatsapp+Web-sharing THY diş hat uçuşlara 18 Haziran'da başliyor

Euronews, (2020b). https://tr.euronews.com/2020/06/04/d-s-hat-ucak-seferleri-10-haziran-dan-itibaren-40-ulkeyegerceklestirilecek (13.05.2021)

Euronews, (2020a). https://tr.euronews.com/2020/06/02/turk-hava-yollar-4-haziran-dan-itibaren-ic-hat-seferleriniart-r-yor (13.05.2021)

Hofstede Insights. (2021). https://www.hofstede-insights.com/product/compare-countries/ (03.10.2021).

Pegasus Hava Yolları, (28.03.2020a). Sabiha Gökçen Havalimanı'ndan Uçuşların Durdurulması Hakkında. https://www.flypgs.com/basin-odasi/duyurular/sabiha-gokcen-havalimanindan-ucuslarindurdurulmasi-hakkinda

Pegasus Hava Yolları, (01.06.2020b). Pegasus Hava Yolları iç hatlarda yolcu uçuşlarına başlıyor https://www.flypgs.com/basin-bultenleri/pegasus-hava-yollari-ic-hatlarda-yolcu-ucuslarina-basliyor 
Pegasus Hava Yolları, (11.06.2020c). Pegasus Hava Yolları yurt dışı uçuşlarına başlıyor https://www.flypgs.com/basinbultenleri/pegasus-hava-yollari-yurt-disi-ucuslarina-basliyor

Pegasus Hava Yolları, (2021a). https://www.flypgs.com/basin-odasi/bultenler

Pegasus Hava Yolları, (2021b). https://www.pegasusyatirimciiliskileri.com/tr/operasyonel-ve-finansalveriler/faaliyet-raporlari

Pegasus Hava Yolları, (2021c). https://www.flypgs.com/bize-yazin/sosyal-medya-bilgilendirme

Sunexpress, $\quad 2020 . \quad$ https://www.sunexpress.com/tr/sirket/basin-odasi/basinbueltenleri/?archive\&category/?archive=herhangi\%20bir\%20zaman\&category=\&showmore=3

Süleyman Demirel Üniversitesi Resmi İnternet Sayfası https:/w3.sdu.edu.tr/haber/9703/covid-19-pandemisurecinde-ve-sonrasinda-turk-sivil-havaciligi (29.05.2021)

THY, (2021). https://www.turkishairlines.com/tr-int/bilgi-edin/bize-ulasin/sosyal-medya/ (02.06.2021)

Türk Hava Yolları 2020 Yıllık Raporu https://investor.turkishairlines.com/documents/yillikraporlar/thy_frat_2020_yillik-rapor.pdf (29.05.2021) 